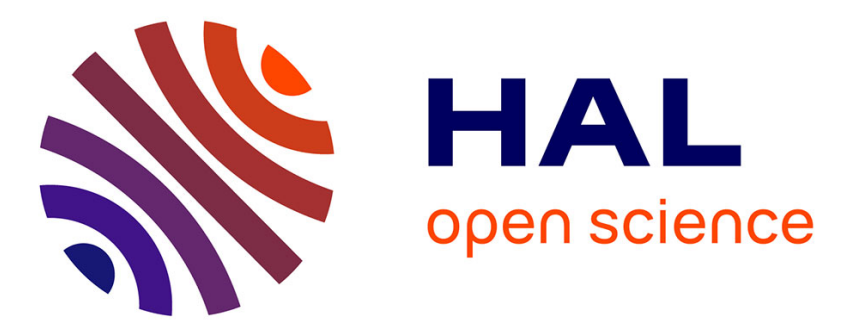

\title{
Simplification of a complex microbial antilisterial consortium to evaluate the contribution of its flora in uncooked pressed cheese
}

\author{
Cecile C. Callon, Marjorie Saubusse, Robert R. Didienne, S Buchin, \\ Marie-Christine M.-C. Montel
}

\section{To cite this version:}

Cecile C. Callon, Marjorie Saubusse, Robert R. Didienne, S Buchin, Marie-Christine M.-C. Montel. Simplification of a complex microbial antilisterial consortium to evaluate the contribution of its flora in uncooked pressed cheese. International Journal of Food Microbiology, 2011, 145 (2-3), pp.379-389. 10.1016/j.ijfoodmicro.2010.12.019 . hal-02644219

\section{HAL Id: hal-02644219 \\ https://hal.inrae.fr/hal-02644219}

Submitted on 28 May 2020

HAL is a multi-disciplinary open access archive for the deposit and dissemination of scientific research documents, whether they are published or not. The documents may come from teaching and research institutions in France or abroad, or from public or private research centers.
L'archive ouverte pluridisciplinaire HAL, est destinée au dépôt et à la diffusion de documents scientifiques de niveau recherche, publiés ou non, émanant des établissements d'enseignement et de recherche français ou étrangers, des laboratoires publics ou privés. 


\title{
Simplification of a complex microbial antilisterial consortium to evaluate the contribution of its flora in uncooked pressed cheese
}

\author{
Cécile Callon ${ }^{\mathrm{a}, *}$, Marjorie Saubusse ${ }^{\mathrm{a}}$, Robert Didienne ${ }^{\mathrm{a}}$, Solange Buchin ${ }^{\mathrm{b}}$, Marie-Christine Montel ${ }^{\mathrm{a}}$ \\ a INRA, UR 545 Fromagères, 20, Côte de Reyne, F-15000 Aurillac, France \\ b INRA, UR 342 Technologie et Analyse Laitière, Rue de Versailles, F-39801 Poligny, France
}

\section{A R T I C L E I N F O}

Article history:

Received 8 July 2010

Received in revised form 17 December 2010 Accepted 21 December 2010

\section{Keywords:}

L. monocytogenes

Raw milk cheese

Inhibition

Microbial communities

\begin{abstract}
A B S T R A C T
A complex microbial consortium derived from raw milk and composed of populations classified in 4 groups (lactic acid bacteria (A), Gram positive catalase positive bacteria (B), Gram negative bacteria (C) and yeasts (D)) can contribute to the inhibition of Listeria monocytogenes in the core of an uncooked pressed cheese. To identify what groups may be involved in the inhibition, the consortium was simplified by successively omitting one group at a time. Pasteurized milk was inoculated with these more or less complex consortia and their effects on L. monocytogenes count, $\mathrm{pH}$, acids and volatile compounds in the core of uncooked pressed cheese were evaluated. The growth of $L$. monocytogenes was the highest in cheeses prepared with pasteurized milk and only St. thermophilus. Inhibition in other cheeses was expressed by comparison with growth in these ones. All the consortia containing both lactic acid bacteria (group A) and Gram positive catalase positive bacteria (group $B$ ) - $A B C D, A B D, A B C, A B$ - were more inhibitory than those containing lactic acid bacteria on its own (A) or associated only with yeasts (AD) or/and Gram negative (ADC). Consortia without lactic acid bacteria were weakly inhibitory or had no effect. Gram positive catalase positive bacteria alone were not inhibitory although most of the species became established in the cheeses. The Lactobacillus population (Lb. casei, Lb. plantarum, Lb. curvatus and Lb. farciminis) was predominant in cheeses ( $9 \log \mathrm{CFU} / \mathrm{g}$ ) with a higher count than Leuconostoc ( $7 \log \mathrm{CFU} / \mathrm{g}$ ) and Enterococcus ( $7 \log \mathrm{CFU} / \mathrm{g}$ ). Lactobacillus counts were negatively correlated with those of $L$. monocytogenes ( $\mathrm{r}=-0.84$ at 18 days) and with the level of D-lactic acid. There was no correlation between L. monocytogenes and Leuconostoc or Enterococcus counts. Complex consortium $A B C D$ and $A B$ not only had a stronger inhibitory power in cheeses than consortium $A D$, they were also associated with the highest levels of L-lactic and acetic acids. All cheeses inoculated with lactic acid bacteria differed from those without by higher levels of ethyl formiate, pentane and alcohols (2-butanol, 2-pentanol), and lower levels of ketones (2-hexanone, 2,3-butanedione) and aldehydes (2-methyl-butanal). Levels of 2-methyl-butanal, 2-butanol and 2-pentanol were higher in $A B C D$ and $A B$ cheeses than in $A D$ cheeses. Beside their contribution to the inhibition, their effect on cheese flavour must be evaluated.
\end{abstract}

Published by Elsevier B.V.

\section{Introduction}

Under current European Community regulations for cheese, at the end of production, Listeria monocytogenes must be absent or less than $100 \mathrm{CFU} / \mathrm{g}$ if it is demonstrated that there is no development during storage until consumption. This can be achieved by monitoring the L. monocytogenes count in milk and applying an appropriate process during manufacturing and ripening. The growth of $L$. monocytogenes during cheese ripening can be reduced by lowering $\mathrm{pH}$ (Margolles et al., 1997; Millet et al., 2006), by cooking the curd or by appropriate salting, temperature and ripening time (Pearson and Marth, 1990). These parameters are not independent and their interactions in

\footnotetext{
* Corresponding author. Tel.: + 3304714564 12; fax: + 330471456413. E-mail address: callon@clermont.inra.fr (C. Callon).
}

Listeria inhibition must be taken into account (Augustin and Carlier, 2000). Inhibition is also linked to the microbial community in the cheese. Biopreservation in cheeses using bacteriocin-producing bacteria has long been widely studied. Indeed, enterocins produced by Enterococcus faecalis and E. faecium (Garcia et al., 1997; Nunez et al., 1997), lacticin or nisin from Lactococcus lactis (O'Sullivan et al., 2006), linocin from Brevibacterium linens (Motta and Brandelli, 2008) and micrococcin from Staphylococcus equorum (Carnio et al., 2000) can inhibit $L$. monocytogenes in the core or at the surface of cheeses. Studies dealing with the inhibition of $L$. monocytogenes in cheeses with complex microbial community have shown that $\mathrm{pH}$ values and/ or production of organic acids may be involved in the inhibition (Millet et al., 2006). They have also suggested that inhibition may be correlated with a high degree of microbial diversity in the community and other unknown factors resulting from microbial interactions (Eppert et al., 1997; Carminati et al., 1999; Maoz et al., 2003; Mayr 
et al., 2004; Roth et al., 2010). None of these studies have clearly demonstrated how microbial populations interact in the inhibition. Is inhibition due to only one species or to a group of microbial species having the same function in the cheese ecosystem (acidification, production of inhibitory compounds)? By comparing the bacterial Single Strand Conformation Polymorphism profiles of St-Nectaire type cheeses with and without antilisterial properties, Saubusse et al. (2007) identified that Lactococcus species, Corynebacterium flavescens and Enterococcus saccharominimus can inhibit L. monocytogenes.

The purpose of the present study is to propose another methodology, based on simplifying an inhibitory community according to the method used by Engel et al. (2002). The microbial community from raw milk studied by Saubusse et al. (2007) was simplified by omitting one microbial group at a time. Uncooked pressed cheeses were prepared with pasteurised milk and each of these more or less complex consortia. The growth of $L$. monocytogenes and other microbial populations were monitored in the cheese cores throughout ripening.

\section{Materials and methods}

\subsection{Experimental methodology}

The raw milk microbial community with antilisterial properties had been previously identified by Saubusse et al. (2007). Omitting Lactococcus because of its strong inhibitory properties and one Gram negative bacteria (Comamonas testosteroni), one strain of each species were selected and classed in 4 groups A, B, C and D as described in Table 1.

Cheeses were prepared with pasteurized milk inoculated with a complex consortium including the 4 groups A, B, C and D, or simplified consortia obtained by omitting one or more of these groups. This simplification was achieved in three successive sets of experiments as indicated in Fig. 1. After each set, the consortium with the strongest antilisterial activity was selected for the next experiment and simplified again by omitting a further microbial group.

\subsection{Cheese manufacturing}

For all experiments, the raw milks were collected from the ENIL farm (Ecole Nationale d'Industrie Laitière) in Aurillac after milking and transported to the cheese experimental plant under refrigerated conditions. It was immediately pasteurized (Pasteurisator Pieralisi PC15-2, Jesy-France) for $30 \mathrm{~s}$ at $72{ }^{\circ} \mathrm{C}$, divided between 6 vats containing $40 \mathrm{~L}$ of milk each and then warmed to $32{ }^{\circ} \mathrm{C}$.

The 29 selected strains of the complex community, the starter culture and the strain of $L$. monocytogenes were separately precultured for $24 \mathrm{~h}$ in $15 \mathrm{~mL}$ of broth media as shown in Table 1. After enumeration on appropriate solid medium (Table 1), each preculture was then centrifuged for $15 \mathrm{~min}$ at $6000 \mathrm{rpm}$. The pellets were diluted in $15 \mathrm{~mL}$ of sterile reconstituted milk added with $15 \%$ of glycerol and stored $1.5 \mathrm{~mL}$ tubes at $-20^{\circ} \mathrm{C}$. For each experiment, one tube per strain was defrosted and diluted to the desired level for inoculation into milk.

For each experiment, all vats of pasteurized milk were inoculated with the strain of St. thermophilus at a concentration of $1.10^{7} \mathrm{CFU} / \mathrm{mL}$ of milk and with L. monocytogenes at 5 to $10 \mathrm{CFU} / 25 \mathrm{~mL}$ of milk. Then each vat was inoculated with a different microbial combination, as described in Fig. 1. The levels of inoculation of each species (Table 1) were defined according to their count in the raw milk from which they were isolated (Saubusse et al., 2007). The composition of the consortia for the 3 experiments was defined as described in Section 2.1.

Small cheeses (600 g) were manufactured according to uncooked pressed cheese technology described by Millet et al. (2006). Cheeses were coated at 1 and 8 days of ripening with orange wax containing natamycin $(1000 \mathrm{ppm})$ to prevent the development of moulds and yeasts on the surface. All cheeses were ripened for 28 days in the Laboratory's ripening cellars at $8{ }^{\circ} \mathrm{C}$ with $95 \%$ relative humidity.

Table 1

Microbial species composition of the different groups A, B, C, and D.

\begin{tabular}{|c|c|c|c|}
\hline Microbial community & $\begin{array}{l}\text { Media for cultivating strains } \\
\text { before inoculation }\end{array}$ & $\begin{array}{l}\text { Levels of inoculation in milk } \\
(\log \mathrm{CFU} / \mathrm{g})\end{array}$ & Taxonomic groups \\
\hline Lactobacillus casei & MRS pH 6.5 at $30^{\circ} \mathrm{C}$ & 4.00 & Goup A \\
\hline Lactobacillus curvatus & (De Man et al., 1960) & 3.00 & Lactic acid bacteria \\
\hline Lactobacillus plantarum & & 4.00 & \\
\hline Lactobacillus farciminis & & 3.00 & \\
\hline Leuconostoc citreum & & 3.00 & \\
\hline Ln, pseudomesenteroides & $\mathrm{M} 17$ at $30^{\circ} \mathrm{C}$ & 3.00 & \\
\hline Enterococcus faecalis & (Terzaghi and Sandine, 1975) & 2.00 & \\
\hline Enterococcus hirae & & 2.00 & \\
\hline Staphylococcus saprophyticus & BHI (Broth Heart Infusion) at $37^{\circ} \mathrm{C}$ & 2.50 & Group B \\
\hline Staphylococcus equorum & (Forney et al., 1985) & 2.50 & Gram positive Catalase positive bacteri \\
\hline Arthrobacter nicotianae & & 3.00 & \\
\hline Corynebacterium flavescens & & 2.00 & \\
\hline Corynebacterium casei & & 2.00 & \\
\hline Brevibacterium linens & & 2.00 & \\
\hline Exiguobacterium $s p$ & & 3.00 & \\
\hline Staphylococcus haemolyticus & & 3.00 & \\
\hline Brachybacterium rhamnosum & & 2.00 & \\
\hline Macrococcus caseolyticus & & 2.00 & \\
\hline Pseudomonas putida & BHI (Broth Heart Infusion) at $25^{\circ} \mathrm{C}$ & 2.00 & Group C \\
\hline Enterobacter amnigenus & (Forney et al., 1985) & 4.00 & Gram negative bacteria \\
\hline Acinetobacter $s p$ & & 2.00 & \\
\hline Chryseobacterium $s p$ & & 2.00 & \\
\hline Stenotrophomonas maltophilia & & 3.00 & \\
\hline Rhodosporidium babjevae & YPG (Yeast Peptone Glucose) at $25^{\circ} \mathrm{C}$ & 2.00 & Group D \\
\hline Debaryomyces hansenii & (Barnett et al., 1990) & 2.00 & Yeasts \\
\hline Candida pseudointermedia & & 2.00 & \\
\hline Candida pararugosa & & 2.00 & \\
\hline Candida deformans & & 2.00 & \\
\hline
\end{tabular}

The different species were combined in the three sets of experiments as indicated in Fig. 1.

The level of inoculation of each species was defined according to their counts in the inhibitory raw milk (Saubusse et al., 2007). 


\section{First experiment}

(6 Vats of pasteurized milk inoculated with different consortia)

vat 1 vat 2 vat 3 vat 4 vat 5 vat 6

$\mathbf{A B C D}^{\mathbf{b}} \mathrm{ADC}^{\mathrm{a}}$ BDC $\mathrm{ABD}$ ABC Control

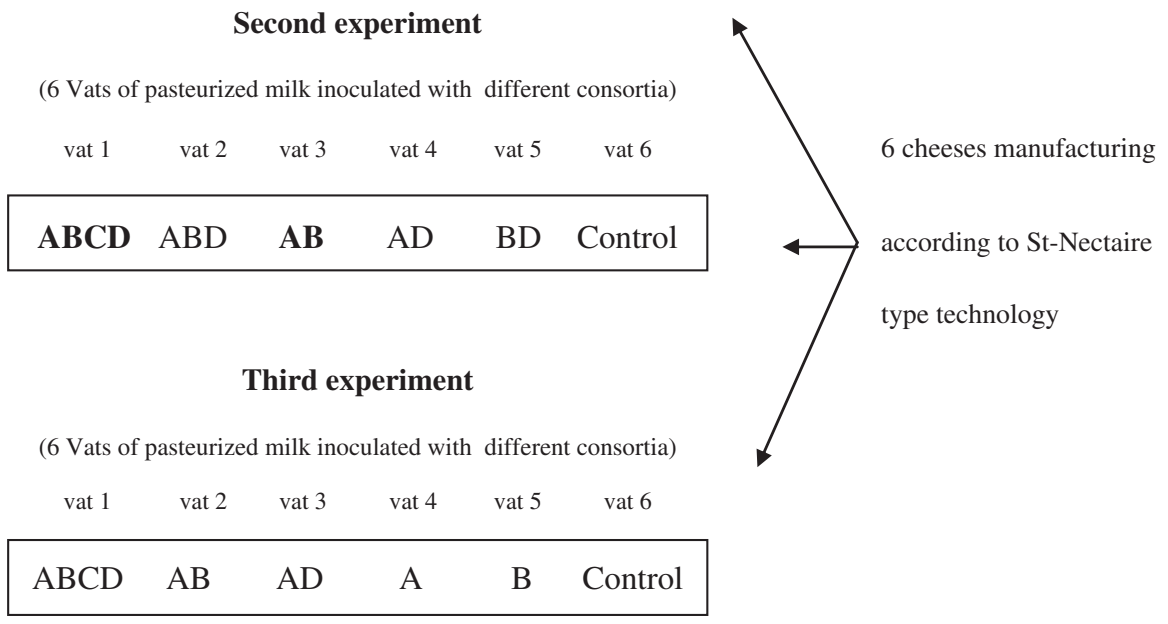

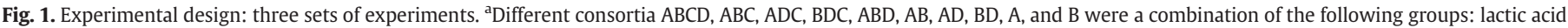

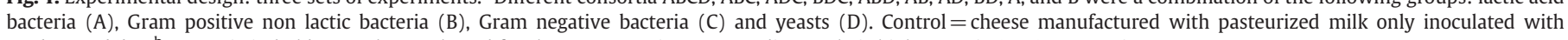
St. thermophilus. ${ }^{\mathrm{b}}$ Consortia in bold were those selected for the next experiment according to their highest anti-Listeria properties.

\subsection{Sampling}

Samples were taken from the inoculated milks and from the cheeses at $1,8,18$ and 28 days of ripening. They were stored at $-20^{\circ} \mathrm{C}$ before microbial and biochemical analysis. L. monocytogenes, $\mathrm{pH}$ and dry matter (DM) were measured on fresh sample cheeses.

\subsection{Physical-chemical analysis}

Cheese $\mathrm{pH}$ (cores and surfaces) were measured with a 926 VTV pH meter with Ingold 406 MX electrode (Mettler-Toledo S.A., Viroflay, France). Dry matter contents were determined according to reference method NFV $046282(12 / 95)$.

\subsection{Acids analysis}

D- and L-lactic acid contents were determined by the enzymatic method. Six grams of cheese were blended in $25 \mathrm{~mL}$ of distilled water by means of a mixer with turbine (Ultra-Turrax, type 125 , Grosseron S.A, Nantes, France) for $1 \mathrm{~min}$ at $9500 \mathrm{rpm}$. After incubation at $40^{\circ} \mathrm{C}$ for $1 \mathrm{~h}$ and centrifugation at $8800 \mathrm{rpm}$ for $30 \mathrm{~min}$ at $4{ }^{\circ} \mathrm{C}$, supernatants were filtered on filters without ash. The contents were determined using the spectrometer method recommended in Diffchamb's EnzyPlus kits (Diffchamb France SARL, Lyon-France). The results were expressed as milligrams per gram of dry matter.

\subsection{Determination of volatile compounds and volatile fatty acids}

Frozen cheese samples were thawed at room temperature $\left(21^{\circ} \mathrm{C}\right)$ and $10 \mathrm{~g}$ of cheese was mixed with $10 \mathrm{~g}$ of dehydrated sodium sulphate (Prolabo, France) before extraction. The volatile compounds of the 1,8 and 28 day old cheeses were extracted by the dynamic headspace method with an automatic Tekmar LSC 3000 system (Cincinnati, Ohio, USA) equipped with a Tenax trap. Ten grams of cheese cut into 12 cubes was placed in a cylindrical glass extractor (diam, $40 \mathrm{~mm}$; height, $120 \mathrm{~mm}$ ). The volatile compounds were extracted under the following conditions: purge helium flow rate of $40 \mathrm{~mL} / \mathrm{min}$; purge of $15 \mathrm{~min}$ at $25^{\circ} \mathrm{C}$; dry purge of $4 \mathrm{~min}$; cryocooldown at $-150{ }^{\circ} \mathrm{C}$; desorb preheat at $225^{\circ} \mathrm{C}$; desorb $2 \mathrm{~min}$ at $220^{\circ} \mathrm{C}$; inject $1 \mathrm{~min}$ at $250^{\circ} \mathrm{C}$ in a gas chromatograph maintained at $40{ }^{\circ} \mathrm{C}$.

The volatile compounds were separated by high resolution gas chromatography (Chromatograph 6890, Hewlett Packard Agilent Technology, Les Ulis, France). Chromatograph conditions were as follows: Supelco capillary column $(60 \mathrm{~m} \times 0.32 \mathrm{~mm}$; RTX5, Restek, Evry-France); stationary phase SPB5 $(1 \mu \mathrm{m})$; carrier gas helium at $2 \mathrm{~mL} / \mathrm{min}$; oven temperature $40{ }^{\circ} \mathrm{C}$ for $6 \mathrm{~min}$, then heated to $230{ }^{\circ} \mathrm{C}$ with a slope of $3^{\circ} \mathrm{C} / \mathrm{min}$.

The volatile compounds were detected by mass spectrometry with a 5973N Hewlett Packard mass spectrometer (Agilent Technology, Les Ulis, France), in scan mode at $70 \mathrm{eV}$. They were then identified by comparing the experimental mass spectra with those contained in the NIST/EPA/MSDC Mass Spectral Database (Royal Society of Chemistry, Milton Road, Cambridge CB4 4WF, UK) and by comparing the experimental retention indices with those of the data bank compiled by Kondjoyan and Berdagué (1996). Each compound was semi-quantified with the arbitrary unit of area of a specific ion (au).

Volatile fatty acids were analyzed by SPME-GC/MS. Five grams of cheese were mixed with $45 \mathrm{~mL}$ of UHQ water using an Ultra-turrax. 400 or $1000 \mu \mathrm{L}$ of this suspension were placed in $10 \mathrm{~mL}$ SPME glass flasks (Supelco, L'isle d'Abeau-France) with 700 or $100 \mu \mathrm{L}$ UHQ water respectively and added with $100 \mu \mathrm{L} \mathrm{H}_{2} \mathrm{SO}_{4} 2 \mathrm{~N}$ and $10 \mu \mathrm{L}$ of 2-ethyl butyric acid $1 \mathrm{ppm}$ as internal standard. The flasks were sealed by aluminium caps with Viton joints. The sample was heated to $60^{\circ} \mathrm{C}$ and the carboxen-PDMS fibre $(0.75 \mathrm{~mm})$ was left in contact with the sample's head-space for $30 \mathrm{~min}$. The desorption of the volatile fatty acids from the fibre into the splitless injector of the GC apparatus lasted $5 \mathrm{~min}$ at $240{ }^{\circ} \mathrm{C}$. The next steps were the same as for volatile 
compounds. An external calibration was performed for all the volatile fatty acids studied, i.e. acetic, propionic, butyric, 2-methyl-propionic, pentanoic, 3-methyl-butyric, 2-methyl-butyric, hexanoic, 3-methylpentanoic acids (Sigma, L'isle d'Abeau-France).

\subsection{Microbial analysis}

L. monocytogenes count was performed in the milk after pasteurization to check its absence, and in the inoculated milk and cheese cores according to ISO 11290-2.

The microbial flora of the milks and cheeses were counted on different culture media: Facultatively Heterofermentative lactobacilli (FH) agar medium (Isolini et al., 1990) at $37^{\circ} \mathrm{C}$ for 3 days under anaerobic conditions, Mayeux Sandine and Elliker (MSE) agar medium (Mayeux et al., 1962) at $30{ }^{\circ} \mathrm{C}$ for $48 \mathrm{~h}$, Slanetz and Bartley (SB) (Slanetz and Bartley, 1957) at $42^{\circ} \mathrm{C}$ for $48 \mathrm{~h}$, Cheese Ripening Bacteria Medium (CRBM) (Denis et al., 2001) at $25^{\circ} \mathrm{C}$ for 10 days, Baird Parker with rabbit plasma (RPF) medium (De Buyser et al., 2003) at $37^{\circ} \mathrm{C}$ for 48 h, and Plate Count Agar (FIL-IDF 100B, 1991) with crystal violet (1\%) and vancomycin (0.5\%) as inhibitor of the Gram positive bacteria (PCAI), Oxytetracyclin Glucose Agar (OGA) medium (Mossel et al., 1962) at $25^{\circ} \mathrm{C}$ for 5 days.

Some media are known to select certain genera: e.g. FH medium for Lactobacillus, MSE medium for dextran-producing Leuconostoc and SB medium for Enterococcus (Callon et al., 2007). The selectivity of CRBM, RPF and PCAI counting media were assessed by identifying representative populations growing on them using a combination of molecular methods. 141 isolates picked up from CRBM, RPF and PCAI counting plates were analyzed by RFLP (Restricted Fragment Length Polymorphism) with ECOR1 and HaeIII enzymes as described by Callon et al. (2007). Total genomic DNAs were extracted from the same counting plates. All the colonies were resuspended in $1 \mathrm{~mL}$ of $4 \mathrm{M}$ of guanidine thiocyanate-Tris $0.1 \mathrm{M}$, N-lauroylsarcosine $10 \%$ and
DNA was extracted with phenol/chloroform DNA method described by Duthoit et al., 2003 in cheese. Total extracted DNA were analyzed by SSCP (Single Strand Conformation Polymorphism) of V2 and V3 regions of DNAr 16 S as described by Callon et al. (2007). Finally, total DNAs of the three media were amplified with species- or genusspecific primers indicated in the literature or developed in the present study, as indicated in Table 2. The specific primers for species C. flavescens, Macrococcus caseolyticus and Enterobacter amnigenus and for genera Acinetobacter and Brachybacterium were designed after aligning 16S rDNA sequences collected from the GenBank database. The specificity of each primers was verified by a BLAST search in NCBI and in the European Ribosomal RNA Database. It was tested by specific PCR primer on all the strains composing the consortium and 9 reference type strains belonging to Corynebacterium casei $\left(\right.$ DPC $5298^{\mathrm{T}}$ ), C. mooreparkense (DPC $5310^{\mathrm{T}}$ ), C. ammoniagenes (CIP $101283^{\mathrm{T}}$ ), A. citreus (CIP 102363), B. linens (ATCC 9175), S. intermedius (DSMZ 20373), S. epidermidis (DSMZ 20044 $4^{\mathrm{T}}$ ), S. hyicus (DSMZ 20459), S. cohnii (DSMZ 20260), S. simulans (DSMZ 20322) and 8 strains from laboratory collection belonging to $C$. flavescens, Arthrobacter nicotianae, Brachybacterium spp., E. amnigenus. PCR amplifications were performed in a final volume of $25 \mu \mathrm{L}$ containing $1 \times$ PCR buffer with $\mathrm{MgCl}_{2}, 0.2 \mathrm{mM}$ each dNTP (Roche Molecular Biomedicals Meylan, France), $0.6 \mu \mathrm{M}$ each primer (Eurogentec France S.A, Angers, France), 0.625 unit Taq DNA polymerase (Appligene Oncor) and $1 \mu \mathrm{L}$ of extracted DNA. PCR reactions were carried out in a thermal cycler Gene Amp PCR System 9700 apparatus (PE Applied Biosystems, Courtaboeuf, France) programmed for an initial denaturating of 4 min at $94{ }^{\circ} \mathrm{C}$ followed by 25 cycles of denaturation for $1 \mathrm{~min}$ at $94{ }^{\circ} \mathrm{C}$, hybridization and elongation $1 \mathrm{~min}$ at $72^{\circ} \mathrm{C}$ and a final elongation $7 \mathrm{~min}$ at $72{ }^{\circ} \mathrm{C}$. Hybridization were performed $45 \mathrm{~s}$ at $60{ }^{\circ} \mathrm{C}$ (C. flavescens), $55^{\circ} \mathrm{C}$ (M. caseolyticus), $62^{\circ} \mathrm{C}$ (Brachybacterium sp. and E. amnigenus), and $58{ }^{\circ} \mathrm{C}$ (Acinetobacter sp.). PCR were verified on $1.5 \%$ agarose gel by the presence of expected fragments at $500 \mathrm{pb}$ for

Table 2

Sequences and references of primers from the literature or from this study used in species or genera specific PCR.

\begin{tabular}{|c|c|c|c|}
\hline Genera or species & Primers & Sequences & References \\
\hline \multirow[t]{2}{*}{ Lactobacillus casei } & $16 \mathrm{rev}$ & 5'GAAAGGAGGTGATCCAGC-3' & Berthier et al., 2001 \\
\hline & paracasei $16 S$ & 5'CACCGAGATTCAACATGG-3' & \\
\hline \multirow[t]{2}{*}{ Lactobacillus plantarum } & 16 forward & 5'GCTGGATCACCTCCTTTC-3' & Berthier and Ehrlich, 1998 \\
\hline & Lpapl & 5'ATGAGGTATTCAACTTATG-3' & \\
\hline \multirow[t]{2}{*}{ Enterococcus faecalis } & ddlE1 & $5^{\prime}$ ATC AAG TAC AGT TAG TCT 3' & Dukta-malen et al., 1995 \\
\hline & ddlE1 & 5'ACG ATT CAA AGC TAA CTG 3' & \\
\hline \multirow[t]{2}{*}{ Enterococcus hirae } & DuHIF & 5' TTA TGT CCC WGT WTT GAA AAA TCA A 3' & Knijff et al., 2001 \\
\hline & HIR & 5'TTT TGT TAG ACC TCT TCC GGA3' & \\
\hline \multirow[t]{2}{*}{ Leuconostoc mesenteroïdes } & Lnm1 & 5' TGTCGCATGACACAAAAGTTA 3' & Cibick et al., 2000 \\
\hline & Lnm2 & 5' ATCATTTCCTATTCTAGCTG 3' & \\
\hline \multirow[t]{2}{*}{ Leuconostoc citreum } & Lncit1 & 5' ACTTAGTATCGCATGATATC 3' & Cibick et al., 2000 \\
\hline & Lncit2 & 5' AGTCGAGTTGCAGACTGCAG 3' & \\
\hline \multirow[t]{2}{*}{ Corynebacterium casei } & Fs15 & 5' CCG CAA GGC TAA AAC TCA AAG GAA T 3' & Monnet et al., 2006 \\
\hline & Fs17 & 5' ACC GAC CAC AAG GGA AAG ACT 3' & \\
\hline \multirow[t]{2}{*}{ Pseudomonas putida } & put f & 5' ATG CTG GTT CGY CGT GGC 3' & Ercolini et al., 2007 \\
\hline & put $\mathrm{r}$ & $5^{\prime}$ TGA TGR CCS AGG CAG ATR CC $3^{\prime}$ & \\
\hline \multirow[t]{2}{*}{ Stenotrophomonas maltophila } & SM1 & 5' CAG CCT GCG AAA AGT A 3' & Whitby et al., 2000 \\
\hline & SM4 & 5' TTA AGC TTG CCA CGA ACA G 3' & \\
\hline \multirow[t]{2}{*}{ Staphycoccus saprophyticus } & sap1 & $5^{\prime}$ TCA AAA AGT TTT CTA AAA AAT TTA C $3^{\prime}$ & Corbiere Morot-Bizot et al., 2004 \\
\hline & sap2 & 5' ACG GGC GTC CAC AAA ATC AAT AGG A 3' & \\
\hline \multirow[t]{2}{*}{ Brevibacterium spp. } & Brevifor & 5' CGG TAC CTS CAG AAG AAG T 3' & Gelsomino et al., 2004 \\
\hline & Brevirev & 5' GTC AGT HAC AGC CCA GAG T 3' & \\
\hline \multirow[t]{2}{*}{ Acinetobacter spp. } & AC1 & 5' ACT TTA AGC GAG GAG GAG GCT 3' & In this study \\
\hline & AC2 & 5' GTC AGT ATT AGG CCA GAT GGC T 3' & \\
\hline \multirow[t]{2}{*}{ Enterobacter amnigenus } & Ea for & 5' GAC TTG GAG GTT GTT CCC TTG 3' & In this study \\
\hline & Ea rev & 5' GCA TGA ATC ACA AAG TGG TAA AGC 3' & \\
\hline \multirow[t]{2}{*}{ Brachybacterium spp. } & Brachyfor & 5' TCG GGA TAA CCT CGG GAA ATC 3' & In this study \\
\hline & Brachyre & 5' CGC ACG CCC GAG GTT G 3' & \\
\hline \multirow[t]{2}{*}{ Macrococcus caseolyticus } & Macfor & 5'-TAG CTT CGC ATG AAG CAA TA-3' & In this study \\
\hline & Macrev & 5'-TTA CGA TCC GAA AAC CTT CTT-3' & \\
\hline \multirow[t]{2}{*}{ Corynebacterium flavescens } & CF1 & 5'-GCC TTT TTT AAG GTG ACG GTA CCT-3' & In this study \\
\hline & CF2 & 5'-ACA AGC CAT CTC TGA CCC AAT C-3' & \\
\hline
\end{tabular}


C. flavescens, $253 \mathrm{pb}$ for M. caseolyticus, $450 \mathrm{pb}$ for Brachybacterium sp., $300 \mathrm{pb}$ for Acinetobacter sp. and $650 \mathrm{pb}$ for E. amnigenus.

\subsection{Data analysis}

Microbial counting results were expressed as log of Colony Forming Unit (CFU) per $\mathrm{mL}$ in milk and per $\mathrm{g}$ in cheese cores.

In order to quantify the differences in L. monocytogenes population between treatments and control throughout ripening, the area of inhibition (AI) between two days ( $\mathrm{t} 1$ and $\mathrm{t} 2$ ) of ripening was calculated using the formula of Wenzel and Marth (1990): AI = (t2 $\mathrm{t} 1) / 2 \times[(\mathrm{Ct} 2+\mathrm{Ct} 1)-(\mathrm{Tt} 2+\mathrm{Tt} 1)]$ where $\mathrm{C}=$ count of $L$. monocytogenes in control cheese inoculated with St. thermophilus and $\mathrm{T}=$ count of L. monocytogenes in trial cheese inoculated with St. thermophilus and other microbial species. The higher the AI values, the stronger the inhibition of L. monocytogenes.

For AI, pH, dry matter (DM), microbial counts, acid contents and volatile compounds data at different ripening times, standard analysis of variance (main-effects ANOVA) was performed to compare the effect of microbial milk inoculation (Statistica software).

Correlations between $L$. monocytogenes growth and variables such as $\mathrm{pH}, \mathrm{DM}$, microbial flora, acid contents and volatile compounds in the cheeses were calculated using Pearson's correlation coefficient.

\section{Results}

\subsection{Inhibition of L. monocytogenes}

The ability of each consortium to inhibit $L$. monocytogenes was evaluated by calculating Area of Inhibition (AI) values as described in the Materials and methods section. The cheeses prepared with milk only inoculated with St. thermophilus were taken as positive controls due the extensive growth of $L$. monocytogenes in the cores. The higher the AI values, the stronger the inhibition of $L$. monocytogenes. To identify the groups most involved in the inhibition, after the first set of experiments, the consortium $\mathrm{ABD}$ with the strongest inhibitory activity was selected for further simplification. ABD was chosen rather than $A B C$ also inhibitory because of the technological interest of yeasts. After the second experiment, as $A B$ was the most inhibitory, the consortiums A and B were separately tested as indicated in Fig. 1. The cheeses can be classed according to their AI values as indicated in Table $3 \mathrm{i}$. Inhibition was strongest in experiment 3 for all inoculations, as illustrated by comparing $A B C D$ consortia in the three experiments. All the consortia containing both lactic acid bacteria (group A) and non lactic acid bacteria (group $B$ ) - ABCD, ABD, $A B C, A B$ - were more inhibitory than those containing lactic acid bacteria alone $(A)$ or associated with yeasts only (AD) or/and Gram negative (ADC). Consortia without lactic acid bacteria were either weakly inhibitory or had no effect (Table $3 \mathrm{i}$ and ii). The Newman-Keuls tests taking into account the results from cheeses prepared twice with the same consortia indicated that the inhibition of $L$. monocytogenes was significantly lower in $A D$ cheeses than in $A B C D$ and $A B$ cheeses throughout ripening (Table 3iii). $A B$ cheese was more inhibitory than $A B C D$ between 8 and 18 days of ripening. Between 18 and 28 days, $A B C D$ and $A B$ cheeses showed the same degree of inhibition. L. monocytogenes grew better in $\mathrm{BD}$ and $\mathrm{B}$ cheeses than in those prepared with only St. thermophilus as indicated by the negative values of their SAI (BD-SAI $=-13.3, \mathrm{~B}-\mathrm{SAI}=-4.4)$.

\subsection{Listeria-pH and Listeria-DM correlations}

In the first and second experiments, cheese $\mathrm{pH}$ varied in a similar way during ripening, regardless of the composition of the microbial consortia inoculated into the milk. The differences in cheese $\mathrm{pH}$ values according to inoculum were below 0.10 until 28 days and was 0.12 at 28 days.

In the third experiment, the $\mathrm{pH}$ value was the same in all cheeses at 1 day, but at 8 and 28 days the $\mathrm{pH}$ of cheeses inoculated only with

Table 3

Classification of cheeses according to the inhibition of L. monocytogenes expressed as AI in reference with cheese with only St. thermophilus.

\begin{tabular}{|c|c|c|c|c|c|c|}
\hline & Trials & Experiment & $\mathrm{AI}(8-1)$ & $\mathrm{AI}(18-8)$ & $\mathrm{AI}(28-18)$ & SAI \\
\hline \multirow[t]{15}{*}{ i) } & $\mathrm{ABCD}$ & 3 & 3.6 & 11.9 & 31.3 & 46.7 \\
\hline & $\mathrm{AB}$ & 3 & -0.8 & 15 & 29.9 & 44 \\
\hline & $\mathrm{ABCD}$ & 1 & 4.7 & 17.2 & 13.5 & 35.4 \\
\hline & $\mathrm{AB}$ & 2 & 1.1 & 7.8 & 23.6 & 32.4 \\
\hline & $\mathrm{ABD}$ & 1 & 0.6 & 12.8 & 16.3 & 29.6 \\
\hline & $\mathrm{ABC}$ & 1 & 1.4 & 11.4 & 16.6 & 29.4 \\
\hline & $\mathrm{AD}$ & 3 & -2.2 & 5.7 & 24.3 & 27.7 \\
\hline & $\mathrm{ABCD}$ & 2 & 3.2 & 6.9 & 16.7 & 26.7 \\
\hline & $\mathrm{ABD}$ & 2 & 1.8 & 2.7 & 18.1 & 22.5 \\
\hline & A & 3 & -4.2 & 5.8 & 19.6 & 21.2 \\
\hline & ACD & 1 & 0.2 & 8.6 & 8.9 & 17.6 \\
\hline & $\mathrm{BDC}$ & 1 & 0 & 7.5 & 5.1 & 12.6 \\
\hline & $A D$ & 2 & -0.1 & 0.5 & 8.4 & 8.8 \\
\hline & B & 3 & 0.2 & -2.5 & -2.2 & -4.4 \\
\hline & $\mathrm{BD}$ & 2 & -2.7 & -6.8 & -3.9 & -13.3 \\
\hline \multirow[t]{2}{*}{ ii) } & $A+$ & $1+2+3$ & $0.78 \pm 2.36$ & $8.9 \pm 4.9$ & $18.9 \pm 7.3$ & $28.5 \pm 10.6$ \\
\hline & $\mathrm{A}-$ & $1+2+3$ & $-0.83 \pm 1.6$ & $-0.6 \pm 0.2$ & $-0.33 \pm 0.1$ & $1.7 \pm 0.5$ \\
\hline \multirow{3}{*}{ iii) } & $\mathrm{ABCD}$ & $2+3$ & $3.4 \pm 0.32$ b & $9.4 \pm 3.5 b$ & $24.0 \pm 10.3 b$ & $36.7 \pm 14.2 b$ \\
\hline & $\mathrm{AB}$ & $2+3$ & $0.1 \pm 1.34$ a & $11.4 \pm 5.06 \mathrm{c}$ & $26.7 \pm 4.5 b$ & $38.2 \pm 8.21 b$ \\
\hline & $\mathrm{AD}$ & $2+3$ & $-1.2 \pm 1.48 a$ & $3.1 \pm 3.64 \mathrm{a}$ & $16.3 \pm 11.2 \mathrm{a}$ & $18.3 \pm 13.4 b$ \\
\hline
\end{tabular}

$\mathrm{AI}=(\mathrm{t} 2-\mathrm{t} 1) / 2 \times[(\mathrm{Ct} 2+\mathrm{Ct} 1)-(\mathrm{Tt} 2+\mathrm{Tt} 1)]$

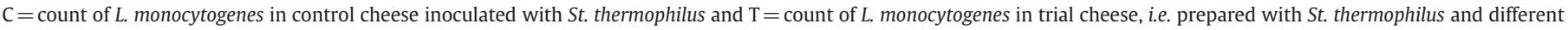
microbial combinations.

$\mathrm{t} 1$ and $\mathrm{t} 2=$ two days of ripening.

$\mathrm{AI}(\mathrm{t} 2-\mathrm{t} 1)$ : area of inhibition between two days of ripening.

$\mathrm{SAI}=\sum \mathrm{AI}$ at all times of ripening.

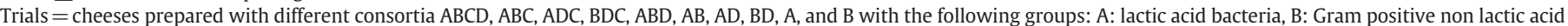
bacteria, C: Gram negative bacteria, and D: yeasts.

i) AI results for the different trials for the 3 experiments, without statistical treatment.

ii) Statistical analysis main-effects ANOVA with $\mathrm{AI}$ in cheeses inoculated with group $\mathrm{A}(\mathrm{A}+)$ or not $(\mathrm{A}-)$.

iii) Statistical analysis ANOVA main-effects with $A I$ in cheeses $A B C D, A B, A D$ of the both experiments 2 and 3 ( 2 replicates).

Means within column with different (in bold in the table) are significantly different $(P<0.2)$ with $\mathrm{a}<\mathrm{b}<\mathrm{c}$ by statistical test of Newman-Keuls. 
Table 4

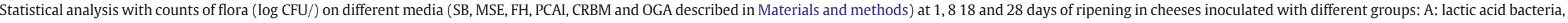
B: Gram positive non lactic acid bacteria, C: Gram negative bacteria and D: yeasts.

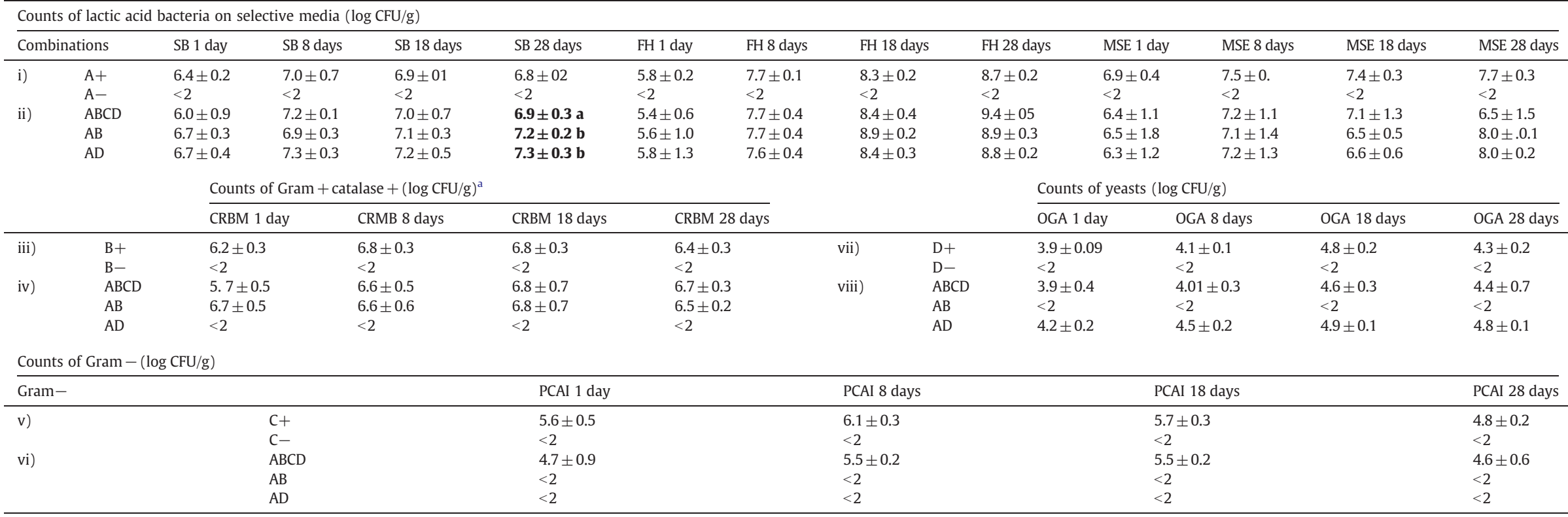

Statistical analysis main-effects ANOVA with counts of flora:

i) in all cheeses inoculated with group $A(A+)$ or not $(A-)$, iii) with group B $(B+)$ or not $(B-)$, v) with group $C(C+)$ or not $(C-)$, vii) with group D (D+) or not (D-).

ii) ii), iv), vi), viii) in cheeses $A B C D, A B, A D$ of the both experiments 2 and 3 (2 repetitions).

Means within column with different letters are significantly different $(P<0.05)$ with $\mathrm{a}<\mathrm{b}$.

ns: non significant by statistical test of Newman-Keuls $(\mathrm{p}<0.05)$

a Level on CRBM have been estimated according to the selectivity and the ratio of Enterococcus identified on this medium (i.e. paragraph 3.3). 
Gram positive catalase positive bacteria had the highest $\mathrm{pH}$ values. At 28 days this was 0.3 units higher than in those with only lactic acid bacteria, which had the lowest $\mathrm{pH}$ values (5.25).

The $L$. monocytogenes count at 28 days was positively correlated with $\mathrm{pH}$ values at $8(\mathrm{r}=0.52, \mathrm{n}=15)$ and 18 days $(\mathrm{r}=0.6, \mathrm{n}=15)$.

The dry mater content of the cheeses varied greatly from 45.7 to 51.0 , according to ripening time and milk inoculation, but there was no correlation with $L$. monocytogenes count $(r=0.18, n=15)$.

\subsection{Microbial analysis}

Lactic acid bacteria can be counted at genus level on media recognized for their selectivity (Callon et al., 2007); their growth during ripening was then evaluated. No lactic acid bacteria were found in cheeses not inoculated with group A (BDC, BD and B, results not shown). First, statistical treatments were applied to microbial data considering all combinations and experiments (Table 4i, iii, v, vii). Then, on the basis of L. monocytogenes results, it was decided to present only the microbial results from cheeses prepared twice with the same consortium $(A B C D, A B$ and $A D$ in the experiments 2 and 3 (Table 4ii, iv, vi, viii)). After 28 days of ripening Lactobacillus (counted on FH medium) was the dominant population in the core of cheeses prepared with group A (Table 4i); its level was over $8.7 \log$ CFU/g. There was no significant difference in the dynamics of Lactobacillus between cheeses $A B C D, A B$ and $A D$ (Table 4ii). In all the 3 cheeses, Lb. curvatus was detected by SSCP analyses (Table 5), and $L b$. casei and $L b$. plantarum by PCR primers, but $L b$. farciminis was not found. Considering all cheeses prepared with group A, L. monocytogenes count at 8 days was negatively correlated with that of Lactobacillus at 1 day $(r=-0.67, n=12)$ and 8 days $(r=-0.75, n=12)$. A negative correlation was observed between the count of $L$. monocytogenes at 28 days and that of Lactobacillus at 18 days $(\mathrm{r}=-0.84, \mathrm{n}=12)$. L. monocytogenes counts at 1 and 18 days were also negatively correlated with the initial level of Lactobacillus $(\mathrm{r}=-0.74, \mathrm{n}=12$ at 1 day and $r=-0.6, n=12$ at 8 days). Inhibition of $L$. monocytogenes was strongest in the third experiment cheeses with the highest initial levels of Lactobacillus.
The level of dextran-producing Leuconostoc on MSE medium reached $7.68 \log \mathrm{CFU} / \mathrm{g}$ at 28 days in cheeses prepared with lactic acid bacteria (Table 4i). There were no significant differences in their dynamics between cheeses $\mathrm{ABCD}, \mathrm{AB}$ and $\mathrm{AD}$ (Table 4ii). Ln. pseudomesenteroides and Leuconostoc citreum were distinguished by their morphology on MSE medium and by specific PCR for Ln. citreum. They were both detected in three cheeses, with higher levels for $L n$. pseudomesenteroides ( $7.7 \log \mathrm{CFU} / \mathrm{g}$ ) than Ln. citreum (5 to $6 \log \mathrm{CFU} /$ g). There was no correlation between $L$. monocytogenes and Leuconostoc count.

Enterococcus on SB medium reached a peak of $6.92 \log \mathrm{CFU} / \mathrm{g}$ at 18 days of ripening (Table $4 \mathrm{i}$ ). Irrespective of the inoculum used, the Enterococcus counts on SB medium (Table 4ii) were not significantly different in cheeses $A B C D, A B$ and $A D$ until 18 days of ripening. At 28 days of ripening, their level was higher in the $A B$ and $A D$ cheeses than in ABCD. It was shown by SSCP, specific PCR, RFLP and counts on SB medium that species E. faecalis and Enterococcus hirae were both present in all the cheeses (Table 5). Whatever the ripening time, there was no correlation between their levels and those of $L$. monocytogenes.

Gram positive non lactic acid bacteria populations were evaluated on CRBM medium after checking the medium's selectivity. Microbial populations growing on CRBM medium were identified by combining different molecular methods (SSCP, RFLP and specific PCR analysis as described in Table 5). The genus Enterococcus represented 62 to 75\% (ratio of Enterococcus peak in SSCP profiles) of colonies on CRBM medium from cheeses inoculated with lactic acid bacteria (results not shown). L. monocytogenes was also found occasionally. Taking this into account, Gram positive catalase positive count was then estimated. It was highest ( $6.8 \log \mathrm{CFU} / \mathrm{g}$ ) at 8 and 18 days of ripening (Table 4iii) and was similar in $\mathrm{ABCD}$ and $\mathrm{AB}$ cheeses at all ripening times (Table 4iv). Combining the results obtained by SSCP, RFLP and specific PCR (Table 5), bacteria of group B inoculated in milk C. casei, A. nicotianae, Exiguobacterium, M. caseolyticus, Staphycoccus saprophyticus and S. equorum - were all detected in cheeses ABCD and $\mathrm{AB}$ whereas $C$. flavescens, Brachybacterium rhamnosum and Staphylococcus haemolyticus were only detected in cheese ABCD and $B$. linens was never detected. There was no correlation between the overall level of all Gram positive catalase positive bacteria and that of

Table 5

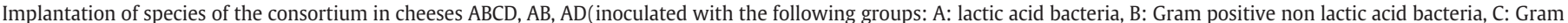

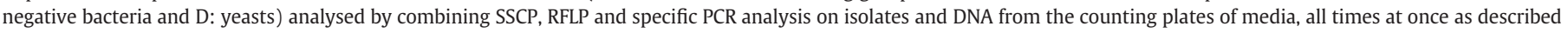
in Materials and methods.

\begin{tabular}{|c|c|c|c|c|c|c|c|c|c|c|c|c|c|c|c|c|c|c|c|c|c|c|c|c|c|c|c|}
\hline \multirow[t]{2}{*}{ Cheeses } & \multirow[t]{2}{*}{ Methods } & \multicolumn{7}{|c|}{ Strains of group A } & \multicolumn{10}{|c|}{ Strains of group B } & \multicolumn{4}{|c|}{ Strains of group C } & \multicolumn{5}{|c|}{ Strain of group D } \\
\hline & & 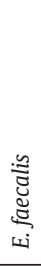 & 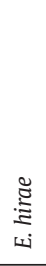 & 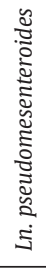 & 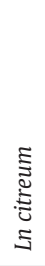 & 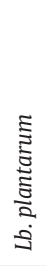 & $\begin{array}{l}\tilde{\Xi} \\
\tilde{U} \\
\tilde{\Xi}\end{array}$ & 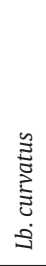 & 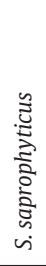 & 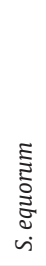 & 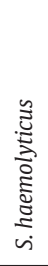 & 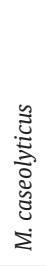 & 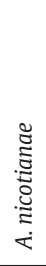 & 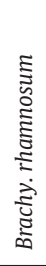 & 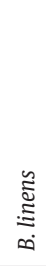 & $\begin{array}{l}\tilde{\tilde{\Xi}} \\
\tilde{U} \\
ن\end{array}$ & 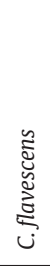 & 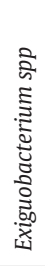 & $\begin{array}{l}\text { D } \\
\stackrel{D}{\Xi} \\
\dot{D} \\
\dot{n}\end{array}$ & 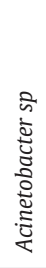 & 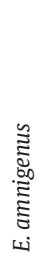 & 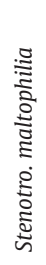 & 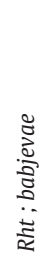 & 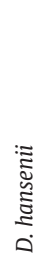 & 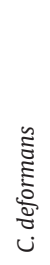 & 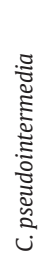 & 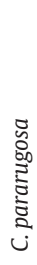 \\
\hline \multirow{4}{*}{$\mathrm{ABCD}$} & RFLP & $\mathrm{x}$ & $\mathrm{x}$ & & & & & & & & & & & $\mathrm{x}$ & & & & & $\mathrm{x}$ & & $\mathrm{x}$ & & & & & & \\
\hline & SSCP & $\mathrm{x}$ & $\mathrm{x}$ & & & & & $\mathrm{x}$ & $\mathrm{x}$ & $\mathrm{x}$ & $\mathrm{x}$ & $\mathrm{x}$ & $\mathrm{x}$ & & & $\mathrm{x}$ & $\mathrm{x}$ & & & & & & & & & & \\
\hline & PCR & $\mathrm{x}$ & $\mathrm{x}$ & & $\mathrm{x}$ & $\mathrm{x}$ & $\mathrm{x}$ & & $\mathrm{x}$ & & & & & & & $\mathrm{x}$ & $\mathrm{x}$ & & $\mathrm{x}$ & & $\mathrm{x}$ & $\mathrm{x}$ & & & & & \\
\hline & Count & $\mathrm{x}$ & $\mathrm{x}$ & $\mathrm{x}$ & $\mathrm{x}$ & & & & & & & & & & & & & $\mathrm{x}$ & & & & & $\mathrm{x}$ & & $\mathrm{x}$ & $\mathrm{x}$ & $\mathrm{x}$ \\
\hline \multirow{4}{*}{$\mathrm{AB}$} & RFLP & $\mathrm{x}$ & $\mathrm{x}$ & & & & & & & & & & & & & & & & & & & & & & & & \\
\hline & SSCP & $\mathrm{x}$ & $\mathrm{x}$ & & & & & $\mathrm{x}$ & $\mathrm{x}$ & $\mathrm{x}$ & & $\mathrm{x}$ & $\mathrm{x}$ & & & $\mathrm{x}$ & & $\mathrm{x}$ & & & & & & & & & \\
\hline & PCR & $\mathrm{x}$ & $\mathrm{x}$ & & $\mathrm{x}$ & $\mathrm{x}$ & $\mathrm{x}$ & & $\mathrm{x}$ & & & & & & & $\mathrm{x}$ & $\mathrm{x}$ & & & & & & & & & & \\
\hline & Count & $\mathrm{x}$ & $\mathrm{x}$ & $\mathrm{x}$ & $\mathrm{x}$ & & & & & & & & & & & & & $\mathrm{x}$ & & & & & & & & & \\
\hline \multirow{4}{*}{$\mathrm{AD}$} & RFLP & $\mathrm{x}$ & $\mathrm{x}$ & & & & & & & & & & & & & & & & & & & & & & & & \\
\hline & SSCP & $\mathrm{x}$ & $\mathrm{x}$ & & & & & $\mathrm{x}$ & & & & & & & & & & & & & & & & & & & \\
\hline & PCR & $\mathrm{x}$ & $\mathrm{x}$ & & $\mathrm{x}$ & $\mathrm{x}$ & $\mathrm{x}$ & & & & & & & & & & & & & & & & & & & & \\
\hline & Count & $\mathrm{x}$ & $\mathrm{x}$ & $\mathrm{x}$ & $\mathrm{x}$ & & & & & & & & & & & & & & & & & & $\mathrm{x}$ & & $\mathrm{x}$ & $\mathrm{x}$ & $\mathrm{x}$ \\
\hline
\end{tabular}

x: species detected, $\square$ : non detected, $\square$ : non researched. 
L. monocytogenes. Nevertheless, they may play a part in inhibition as the inhibition was greater in $A B$ and $A B C D$ cheeses than in $A D$ ones.

In cheeses inoculated with Gram negative bacteria ( $C$ group), the bacterial level on PCAI was $4.8 \mathrm{log}$ CFU/g (Table 4v) but this medium was not selective enough to quantify Gram negative bacteria well. Indeed, Brachybacterium spp. and Staphylococcus (representing up to $24 \%$ of the total population on some counting plates) or E. faecalis and Lactobacillus (40\% of population on some counting plates) were detected by molecular methods on this medium. In ABCD cheese, among Gram negative bacteria inoculated, only Pseudomonas putida, Stenotrophomonas maltophilia, E. amnigenus were present but not Acinetobacter sp. and Chryseobacterium.

The yeast population was only counted in cheeses prepared with this group (Table 4vii) and highest level was $4.8 \log$ CFU/g at 18 days. Regarding the differences in their morphology on OGA medium, it can be concluded that the 4 species Rhodosporidium babjevae, Candida deformans, Candida pararugosa and Candida pseudointermedia were present in cheeses ADCB and AD (Table 5) whereas the species Debaryomyces hansenii was not detected. Yeast levels were similar in ABCD and AD cheeses (Table 4viii). Considering all cheeses inoculated with group $D(n=10)$, their level was not correlated with that of L. monocytogenes. However, between 18 and 28 days of ripening, the presence of yeast reduced the inhibitory effect of lactic acid bacteria: inhibition of Listeria was weaker in ABD cheese than in $A B$ cheese in the experiment 2 , and weaker in $A D$ cheese than in $A$ cheese in experiment 3 , as shown in Table 3iii.

\subsection{Acid contents}

The effect on cheese acid content of the presence or absence of lactic acid bacteria in cheeses was analyzed (Table 6i). The D-lactic acid contents at 8,18 and 28 days were significantly higher in cheeses prepared with lactic acid bacteria (group A) than without, whereas the L-lactic acid contents at 8 and 18 days were similar in the two kinds of cheese. Moreover, L-lactic acid was present at the same level in the control cheese prepared with only St. thermophilus, so it may be produced by this species. Butyric and hexanoic acid contents were similar at 1 day in cheese with or without the group A but at 28 days, they were significantly higher in cheeses with A than in those without (Table 6i). This was also true of acetic acid at both 8 and 28 days. These different levels of a number of acids may explain the lack of inhibition in cheeses without lactic acid bacteria in the consortia. The levels of 3-methyl-butyric acid at 28 days were higher in cheeses without A.

The acid contents in $A B C D, A B$ and $A D$ cheeses were compared by main-effects ANOVA for cheeses manufactured twice with the same microbial consortia (Table 6ii). At 8 and 28 days the D-lactic acid content was significantly higher in cheeses $A B$ than in cheeses $A B C D$ or $A D$. In all cheeses it increased throughout the ripening. Dlactic acid contents were strongly negatively correlated with the
L. monocytogenes count (at 1 day, $\mathrm{r}=-0.89, \mathrm{n}=15$ and at 18 days $\mathrm{r}=$ $-0.75, \mathrm{n}=15$ ). Moreover, D-lactic acid at 18 and 28 days was strongly correlated with Lactobacillus levels at every ripening time $(r=0.80$ to 0.90 ). Similarly, there was a strong positive correlation between D-lactic acid and Leuconostoc levels at 28 days ( $\mathrm{r}=0.77, \mathrm{n}=15$ ).

At 28 days of ripening the L-lactic acid content was similar in cheeses $A B C D$ and $A B(19.4$ and $17.6 \mathrm{mg} / \mathrm{g}$ ) but lowest in cheese AD $(14.6 \mathrm{mg} / \mathrm{g}$ ) due to a decrease between 18 and 28 days of ripening. Whatever the ripening time, there was no correlation between Listeria count and L-lactic acid content. No correlation was found between L-lactic acid contents and microflora counted on different media.

Acetic acid content increased in the 3 cheeses $A B C D, A B$ and $A D$ until 28 days. It was similar in the 3 cheeses at 8 days but at 28 days, it was lower in $A D$ cheese than in $A B C D$ and $A B$ (Table 6ii). The correlation between acetic acid content and L. monocytogenes counts during ripening $(\mathrm{r}<0.5, \mathrm{n}=15)$ was weak. There was a positive correlation between acetic acid content at 28 days and Leuconostoc levels at 1 to 28 days $(r=0.65$ at 1 day and $r=0.78$ at 28 days, $\mathrm{n}=15$ ).

Butyric and hexanoic acid contents were significantly higher in $A B$ cheese than in $A B C D$ or $A D$ at 28 days (Table 6ii).

\subsection{Volatile compounds}

136 volatile compounds were identified by GC/MS analysis. They were aldehydes (14 compounds), alcohols (15), ketones (18), esters (10), sulphur compounds (5), furans (6), ethers (1), alcanes (20), alcenes (7), benzene derivatives (12), terpenes (8), chloride derivatives (4) and nitrogen derivatives (2). But the levels of only 7 volatile compounds varied according to the consortia inoculated.

All cheeses inoculated with lactic acid bacteria were distinguished from those without by higher levels (arbitrary units of area) of ethyl formiate, pentane and alcohols (2-butanol, 2-pentanol), and lower levels of ketones (2-hexanone, 2,3-butanedione) and aldehydes (2-methyl-butanal) (Table 7i).

Levels of 2-methyl-butanal, 2-butanol and 2-pentanol were higher in $A B C D$ and $A B$ cheeses than in $A D$ (Table 7ii). Levels of other compounds were similar between these 3 consortia.

Counts of $L$. monocytogenes at 28 days were negatively correlated with 2-butanol and 2-pentanol at 28 days $(r=-0.8$ and $r=-0.7$, $\mathrm{n}=15$ ). Both compounds were positively correlated with lactic acid bacteria (same value of $r=0.9$ with counts of Lactobacillus on FH medium, Enterococcus on SB medium and Leuconostoc on MSE medium, $\mathrm{n}=15$ ).

\section{Discussion}

The simplification methodology was effective for identifying microbial groups of a complex microbial consortium involved in the inhibition of $L$. monocytogenes compared to its growth in cheeses

Table 6

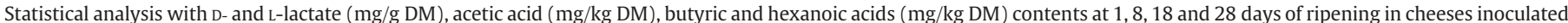
with different groups: A: lactic acid bacteria, B: Gram positive non lactic acid bacteria, C: Gram negative bacteria and D: yeasts.

\begin{tabular}{|c|c|c|c|c|c|c|c|c|c|c|c|c|c|}
\hline & \multirow[t]{2}{*}{ Cheeses } & \multicolumn{3}{|l|}{ D-lactic acid } & \multicolumn{3}{|c|}{ L-lactic acid } & \multicolumn{2}{|l|}{ Acetic acid } & \multicolumn{2}{|c|}{ Butyric acid } & \multicolumn{2}{|c|}{ Hexanoic acid } \\
\hline & & 8 days & 18 days & 28 days & 8 days & 18 days & 28 days & 8 days & 28 days & 1 day & 28 days & 1 day & 28 days \\
\hline \multirow[t]{2}{*}{ i) } & $\mathrm{A}+$ & $2.6 \pm 0.4 b$ & $5.5 \pm 0.5 \mathrm{~b}$ & $7.0 \pm 0.5 b$ & $17.7 \pm 0.7$ & $19.1 \pm 0.6$ & $18.4 \pm 1.0$ & $612 \pm 223 b$ & $1490 \pm 236 b$ & $1.6 \pm 0.8$ & $46.4 \pm 23 b$ & $1.2 \pm 0.5$ & $18.6 \pm 13.6 \mathrm{~b}$ \\
\hline & $A-$ & $1.3 \pm 0.6 \mathrm{a}$ & $0.8 \pm 0.7 a$ & $0.7 \pm 0.6 a$ & $19.0 \pm 0.6$ & $20.9 \pm 2.8$ & $18.2 \pm 4.4$ & $74 \pm 34 a$ & $178 \pm 95 a$ & $1.5 \pm 1.5$ & $20.1 \pm 10.5 a$ & $1.2 \pm 1.2$ & $3.9 \pm 3.9 \mathrm{a}$ \\
\hline \multirow[t]{3}{*}{ ii) } & ${ }^{*} \mathrm{ABCD}$ & $3.0 \pm 1.5 a$ & $4.8 \pm 2.3$ & $6.6 \pm 1.9$ & $18.0 \pm 2.0$ & $18.1 \pm 1.9$ & $19.4 \pm 1.3 b$ & $630 \pm 194$ & $1167 \pm 263$ & $3.0 \mathrm{~b}$ & $23.3 \pm 9.3 \mathrm{a}$ & 2.5 & $5.5 \mathrm{a}$ \\
\hline & $\mathrm{AB}$ & $3.5 \pm 1.6 \mathrm{~b}$ & $5.7 \pm 2.2$ & $7.1 \pm 1.4$ & $18.3 \pm 3.3$ & $17.2 \pm 0.6$ & $17.6 \pm 0.6 b$ & $664 \pm 35$ & $1305 \pm 735$ & $3.8 \mathrm{~b}$ & $55.1 \pm 34 b$ & 2.0 & $17.2 \mathrm{~b}$ \\
\hline & $A D$ & $3.3 \pm 1.5 a b$ & $5.9 \pm 1.5$ & $6.2 \pm 0.7$ & $16.8 \pm 1.8$ & $18.5 \pm 1.5$ & $14.6 \pm 1.1 \mathrm{a}$ & $613 \pm 237$ & $903 \pm 228$ & $0.0 \mathrm{a}$ & $15.1 \pm 14 a$ & 1.1 & $8.2 \mathrm{a}$ \\
\hline
\end{tabular}

D- and L-lactic acids have been analyzed by enzymatic kits. Acetic and volatile fatty acids have been analyzed by CPG.

Statistical analysis main-effects ANOVA of acid contents:

i) in cheeses inoculated with group $\mathrm{A}(\mathrm{A}+)$ or not $(\mathrm{A}-)$.

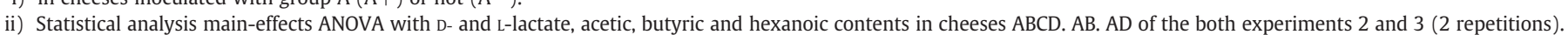

Means within column with different letters are significantly different $(P<0.05)$ with $\mathrm{a}<\mathrm{b}$ according to statistical test of Newman-Keuls. 
Table 7

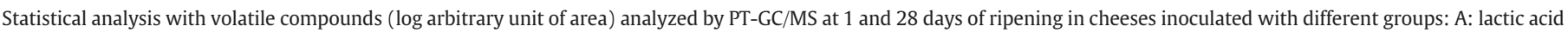
bacteria, B: Gram positive non lactic acid bacteria, C: Gram negative bacteria and D: yeasts.

\begin{tabular}{|c|c|c|c|c|c|c|c|c|c|c|c|c|c|c|c|}
\hline & & \multicolumn{2}{|c|}{ 2-methyl-butanal } & \multicolumn{2}{|c|}{ 2-butanol } & \multicolumn{2}{|c|}{ 2-pentanol } & \multicolumn{2}{|c|}{ 2-hexanone } & \multicolumn{2}{|c|}{ 3-methyl-2-butanone } & \multicolumn{2}{|c|}{ Ethyl formiate } & \multicolumn{2}{|c|}{ Pentane } \\
\hline & & 1 day & 28 days & 1 day & 28 days & 1 day & 28 days & 1 day & 28 days & 1 day & 28 days & 1 day & 28 days & 1 day & 28 days \\
\hline \multirow[t]{2}{*}{ i) } & $\mathrm{A}+$ & 4.1 & 3.9 & $4.7 \mathrm{~b}$ & $5.9 \mathrm{~b}$ & 3.5 & $6.3 \mathrm{~b}$ & 3.1 & $3.4 \mathrm{a}$ & 1.7 & 2.1 & 2.9 & $4.5 \mathrm{~b}$ & 4.5 & $4.4 \mathrm{~b}$ \\
\hline & A- & 4.2 & 3.7 & $4.0 \mathrm{a}$ & $4.5 \mathrm{a}$ & 2.5 & 2.9 a & 3.3 & $4.5 \mathrm{~b}$ & 1.8 & 3.0 & 2.6 & $3.3 \mathrm{a}$ & 4.4 & $3.1 \mathrm{a}$ \\
\hline \multirow[t]{3}{*}{ ii) } & $A B C D$ & $4.1 \mathrm{~b}$ & 4.1 & $5.1 \mathrm{~b}$ & 5.9 & $4.4 \mathrm{c}$ & 6.3 & 4.0 & 3.1 & 3.1 & 3.4 & 3.0 & 4.5 & 4.7 & 4.7 \\
\hline & $\mathrm{AB}$ & $4.2 \mathrm{~b}$ & 3.7 & $5.0 \mathrm{~b}$ & 5.8 & $4.2 \mathrm{~b}$ & 6.4 & 3.7 & 2.9 & 2.9 & 3.8 & 3.1 & 4.5 & 4.9 & 4.8 \\
\hline & $A D$ & $3.7 \mathrm{a}$ & 4.5 & $4.7 \mathrm{a}$ & 6.1 & 3.7 a & 6.5 & 4.1 & 2.0 & 2.0 & 3.2 & 2.8 & 4.7 & 4.7 & 4.9 \\
\hline
\end{tabular}

Statistical analysis main-effects ANOVA with volatile compound contents:

i) in cheeses inoculated with group $A(A+)$ or not $(A-)$.

ii) in cheeses $A B C D, A B, A D$ of the both experiments 2 and 3 (2 repetitions).

Means within column with different letters are significantly different $(P<0.2)$ with $\mathbf{a}<\mathrm{b}<\mathrm{c}$ according to statistical test of Newman-Keuls.

inoculated only with St. thermophilus. The omission of Gram negative bacteria (group $C$ ) from $A B C D$ did not change the inhibition of $L$. monocytogenes, whereas the omission of yeasts (group D) decreased it. It was concluded that, during ripening, lactic acid bacteria had the most significant effect on Listeria inhibition but that the addition of the ripening bacteria (group B) increased the inhibition. Inhibition was correlated mainly with the level of Lactobacillus, suggesting the role of this genus as mentioned by Gay and Amgar (2005) in Camembert cheeses.

The strongest interaction for the inhibition was found when lactic acid bacteria ( $\mathrm{Lb}$. casei, Lb. plantarum, Lb. farciminis, Lb. curvatus, $\mathrm{Ln}$. citreum, Ln. pseudomesenteroides, E. faecalis, E. hirae) were associated with Gram + catalase + bacteria detected in AB cheeses (C. casei, C. flavescens, A. nicotianae, S. saprophyticus, S. equorum, M. caseolyticus, Exiguobacterium spp.). Saubusse et al. (2007) have pointed out that $C$. flavescens inoculated into milk can inhibit $L$. monocytogenes. Low $\mathrm{pH}$ can contribute to the inhibition as the growth of L. monocytogenes in the experiment 3 was the highest when the $\mathrm{pH}$ was the highest.

Inhibition was associated with levels of D-lactic acid, L-lactic acid and acetic acid. These acids may act in synergy, especially at the end of ripening. Le Marc et al. (2002) modeled the growth kinetics of Listeria innocua as a function of $\mathrm{pH}$ values from 4.5 to 9.4, the undissociated forms of lactic acid, acetic and propionic contents and temperature values. The minimum inhibitory concentrations of undissociated acids were $8 \mathrm{mM}$ for lactic acid, $20.3 \mathrm{mM}$ acetic acid and $8.8 \mathrm{mM}$ for propionic acid. L. monocytogenes may also be more sensitive to D-lactic acid than L-lactic acid (Gravesen et al., 2004). Millet et al. (2006) also pointed out that the inhibition of $L$. monocytogenes may be due to lactic acid content at concentrations above $14 \mathrm{mg} / \mathrm{g}$ in cheese. The correlations suggest that, in our consortia, bacterial populations able to produce D-lactic acid may have been $L b$. plantarum, $L b$. curvatus, $L n$. pseudomesenteroides, Ln. citreum but not Gram + catalase + bacteria. This may explain why the latter on their own were not inhibitory. The decrease in L-lactic acid at 28 days of ripening in cheeses inoculated with lactic acid bacteria and yeast is not surprising, as yeasts C. deformans and C. pararugosa are able to consume it.

The highest level of acetic acid was produced when lactic acid bacteria and Gram + catalase + bacteria were associated. Then, these both groups can be involved in this production. Heavin et al. (2009) showed that the growth of $L$. monocytogenes in a synthetic medium was reduced by $50 \%$ by $3000 \mathrm{mg} / \mathrm{kg}$ of acetic acid, but this concentration is higher than those found in our cheeses mesophilic lactobacilli such as $L b$. plantarum or $L b$. casei can produce acetic acid from lactose, citrate or amino acid metabolism (Palles et al., 1998; Skeie et al., 2008; Hussain et al., 2009; Ong and Shah, 2009).

Butyric and hexanoic acids were only detected in the cheeses in experiment 3 with the highest levels of Lactobacillus, that were most strongly inhibitory. $L b$. casei, $L b$. acidophilus, $L b$. rhamnosus were able to produce these acids by lipolysis of milk fat (Yadav et al., 2007; Ong and Shah, 2009), or by amino acid catabolism (Ganesan et al., 2004).
Butyric acid was detected in ewe's milk cheeses prepared with $L b$. casei and $L b$. plantarum (Irigoyen et al., 2007). Hexanoic acids at $530 \mathrm{mg} / \mathrm{kg}$, at upper concentration than in our study, inhibited L. monocytogenes in a soft blue cheese with Pen. roqueforti (Kinderlerer and Lund, 1992).

Among volatile compounds only 2-3-butanedione, acetoine and 2-3 butanediol has been described as bactericide against Listeria at concentration upper than $100 \mathrm{ppm}$ (Lanciotti et al., 2003). In our study these compounds were not in highest concentration in inhibitory cheeses. In spite of higher concentrations of some alcohols, aldehydes, ketones, esters in inhibitory cheeses with lactic acid bacteria, their contribution in L. monocytogenes inhibition is still questionnable because their causal effect was not demonstrated. They can be only an indicator of the good establishment of some flora. Production of volatile compounds by the consortium $A B$ associating lactic acid bacteria and Gram + catalase + bacteria could have a positive effect on the flavour of cheese. Indeed, this consortium was tested in a farm producing raw milk PDO St-Nectaire cheese (cf deliverable D61.1.2 of Truefood project www.truefood. $\mathrm{eu}$ ). The cheeses with the consortium were significantly more elastic by finger touching and more sticky and melting in mouth than the control cheese prepared without the consortium. It had more intense butter and pungent odor and higher intensity and salted, acid taste and mould aroma scores but less "hard cooked cheese" and dried fruit aroma than control cheeses.

The inhibition may be due to other metabolites or to nutrient competition by these flora. Bacteriocins were probably not involved as by agar plate method they were not detected in any strain of the consortium (Saubusse et al., 2007). But their absence in cheese remains to be checked.

Our omission methodology can help to identify microbial groups of complex consortium with promising anti-listerial effects. It could constitute an alternative to the various interesting methods described by Monnet et al. (2009) for screening anti-listerial activity. It could contribute to the understanding of microbial interactions responsible of inhibition by complex consortiums associating several coryneform bacteria (C. casei, C. variabile, B. linens, M. gubbeenense and Arthrobacter) (Eppert et al., 1997, Maoz et al., 2003; Mayr et al., 2004; Roth et al., 2010). For defining simplified consortium our approach should also be based on the evaluation of strains of consortium to produce or consume different acids (lactic, acetic, hexanoic acids...). This will help to define simplified consortium.

The "Jameson effect" described by Mellefont et al. (2008) and pointed out by Guillier et al. (2008) to explain inhibition of Listeria on wood may not have occurred in our cheeses. In our study, lactic acid bacteria were at high levels in all cheeses inoculated with $A$, but the inhibition varied nevertheless (weaker in $A D$ cheeses than in $A B$ ).

Our results also suggest that the inhibition can be linked to functional microbial groups producing inhibitory substances that can be counteracted by other species consuming them. They also argue for 
the antilisterial properties of all these species isolated from raw milk. Studies are in progress to evaluate these mechanisms.

\section{Acknowledgments}

This work received funding from the TRUEFOOD, "Traditional United Europe Food," an integrated project financed by the European Commission under the 6th Framework Programme for RTD (contract no. FOOD-CT-2006-016264).

The authors also sincerely thank R. Lavigne and B. Desserre for their technical assistance concerning cheesemaking and microbial analysis.

English revision was done by Harriet Coleman.

\section{References}

Augustin, J.C., Carlier, V., 2000. Modelling the growth rate of Listeria monocytogenes with a multiplicative type model including interactions between environmental factors. International Journal of Food Microbiology 56, 53-70.

Barnett, J.A., Payne, R.W., Yarrow, D., 1990. Yeasts: Characteristics and Identification, Second Ed. Cambridge University Press, Cambridge, England.

Berthier, F., Ehrlich, S.D., 1998. Rapid species identification within two groups of closely related lactobacilli using PCR primers that target the 16S/23S rRNA spacer region. FEMS Microbiology Letters 161, 97-106.

Berthier, F., Beuvier, E., Dasen, A., Grappin, R., 2001. Origin and diversity of mesophilic lactobacilli in Comte cheese, as revealed by PCR with repetitive and species-specific primers. International Dairy Journal 11, 293-305.

Callon, C., Duthoit, F., Delbès, C., Ferrand, M., Le Frileux, Y., 2007. Stability of microbial communities in goat milk during a lactation year: molecular approaches. Systematic and Applied Microbiology 30, 547-560.

Carminati, D., Neviani, E., Ottogalli, G., Giraffa, G., 1999. Use of surface-smear bacteria for inhibition of Listeria monocytogenes on the rind of smear cheese. Food Microbiology $16,29-36$.

Carnio, M.C., Holtzel, A., Rudolf, M., Henle, T., Jung, G., Sherer, S., 2000. The macrocyclic peptide antibiotic micrococcin P1 is secreted by the food-borne bacterium Staphylococcus equorum WS 2733 and inhibits Listeria monocytogenes in soft cheese. Applied and Environmental Microbiology 66, 2378-2384.

Cibick, R., Lepage, E., Tailliez, P., 2000. Molecular diversity of Leuconostoc mesenteroides and Leuconostoc citreum isolated from traditional French cheeses as revealed by RAPD fingerprinting, 16S rDNA sequencing and 16S rDNA fragment amplification. Systematic and Applied Microbiology 23, 267-278.

Corbiere, Morot-Bizot S., Talon, R., Leroy, S., 2004. Development of a multiplex PCR for the identification of Staphylococcus genus and four staphylococcal species isolated from food. Journal of Applied Microbiology 97, 1087-1094.

De Buyser, M.L., Lombard, B., Schulten, S.M., In't Veld, P.H., Scotter, S.L., Rollier, P., Lahellec, C., 2003. Validation of EN ISO standard methods 6888 Part 1 and part 2: 1999-enumeration of coagulase-positive staphylococci in foods. International Journal of Food Microbiology 83, 185-194.

De Man, J.C., Rogosa, M., Sharpe, M.E., 1960. A medium for the cultivation of Lactobacilli. The Journal of Applied Bacteriology 23, 510-522.

Denis, C., Gueguen, M., Henry, E., Levert, D., 2001. New media for the numeration of cheese surface bacteria. Le Lait $81,365-379$.

Dukta-malen, S., Evers, S., Courvalin, P., 1995. Detection of glycopeptide resistance genotypes and identification to the species level of clinically relevant enterococci by PCR. Journal of Clinical Microbiology 33, 24-27.

Duthoit, F., Godon, J.J., Montel, M.C., 2003. Bacterial community dynamics during production of Registered Designation of Origin Salers cheese as evaluated by $16 \mathrm{~S}$ rRNA gene Single Strand Conformation Polymorphism analysis. Applied and Environmental Microbiology 69, 3840-3848.

Engel, E., Nicklaus, S., Salles, C., Le Quéré, J.L., 2002. Relevance of omission tests to determine flavour-active compounds in food: application to cheese taste. Food Quality and Preference 13, 505-513.

Eppert, I., Valdes-Stauber, N., Götz, H., Busse, M., Sherer, S., 1997. Growth reduction of Listeria spp. caused by undefined industrial red smear cheese cultures and bacteriocin-producing Brevibacterium linens as evaluated in situ on soft cheese. Applied and Environmental Microbiology 63, 4812-4817.

Ercolini, D., Russo, F., Blaiotta, G., Pepe, O., Mauriello, G., Villani, F., 2007. Simultaneous detection of Pseudomonas fragi, $P$. lundensis, and $P$. Putida from meat by use of a multiplex PCR assay targeting the carA gene. Applied and Environmental Microbiology 73, 2354-2359.

Forney, J.E., Miller, J.M., 1985. Quality control of culture media, In: Lennette, E.H. Balows, A., Hausler Jr., W.J., Shadomy, H.J. (Eds.), Manual of Clinical Microbiology, 4th Ed. American Society for Microbiology, Washington, D.C, pp. 1054-1065.

Ganesan, B., Seefeldt, K., Koka, R.C., Dias, B., Weimer, B.C., 2004. Monocarboxylic acid production by lactococci and lactobacilli. International Dairy Journal 14, 237-246.

Garcia, E., Depaz, M., Gaya, P., Medina, M., Nunez, M., 1997. Inhibition of Listeria innocua in manchego cheese by bacteriocin-producing Enterococcus faecalis inia 4. Milk Science International 52, 667-670.

Gay, M., Amgar, A., 2005. Factors moderating Listeria monocytogenes growth in raw milk and in soft cheese made from raw milk. Le Lait 85, 153-170.
Gelsomino, R., Vancanneyt, M., Vandekerckhove, T.M., Swings, J., 2004. Development of a 16S rRNA primer for the detection of Brevibacterium spp. Letters in Applied Microbiology 38, 532-535.

Gravesen, A., Diao, Z., Voss, J., Budde, B.B., Knochel, S., 2004. Differential inactivation of Listeria monocytogenes by D- and L-lactic acid. Letters in Applied Microbiology 39 528-532.

Guillier, L., Stahl, V., Hezard, B., Notz, E., Briandet, R., 2008. Modelling the competitive growth between Listeria monocytogenes and biofilm microflora of smear cheese wooden shelves. International Journal of Food Microbiology 128, 51-57.

Heavin, S.B., Brennan, O.M., Morissey, J.P., O'Byrne, C.P., 2009. Inhibition of Listeria monocytogenes by acetate, benzoate and sorbate: weak acid tolernace is not influenced by the glutamate decarboxylase system. Letters in Applied Microbiology 49, 179-185.

Hussain, M.A., Rouch, D.A., Britz, M.L., 2009. Biochemistry of non-starter lactic acid bacteria isolate Lactobacillus casei GCRL163: production of metabolites by stationary-phase cultures. International Dairy Journal 19, 12-21.

IDF, 1991. Milk and Milk Products. Microorganisms. Colony Count at $30^{\circ} \mathrm{C}$. FIL-IDF Standard 100B. International Dairy Federation.

Irigoyen, A., Ortigosa, M., Juansaras, I., Oneca, M., Torre, P., 2007. Influence of an adjunct culture of Lactobacillus on the free amino acids and volatile compounds in a Roncaltype ewe's-milk cheese. Food Chemistry 100, 71-80.

Isolini, D., Grand, M., Glättli, H., 1990. Selektivmedien zum nachweis von obligat und fakultativ heterofermentativen Laktobazillen. Schweizerische Milchwirtschaftliche Forshung 19, 57-59.

Kinderlerer, J.L., Lund, B.M., 1992. Inhibition of Listeria monocytogenes and Listeria innocua by hexanoic and octanoic acids. Letters in Applied Microbiology 14, 271-274.

Knijff, E., Dellaglio, F., Lombardi, A., Andrighetto, C., Torriani, S., 2001. Rapid identification of Enterococcus durans and Enterococcus hirae by PCR with primers targeted to the ddl genes. Journal of Microbiology Methods 47, 35-40.

Kondjoyan, N., Berdagué, J.L., 1996. A compilation of relative retention indices for the analysis of volatile compounds. $234 \mathrm{pp}$. Edition du Laboratoire Flaveur. Station de recherche sur la viande, INRA de Theix, Saint Genes Champanelle, France.

Lanciotti, R., Patrignani, F., Bagnolini, F., Guerzoni, M.E., Gardini, F., 2003. Evaluation of diacethyl antimicrobial activity against Escherichia coli, Listeria monocytogenes and Staphylococcus aureus. Food Microbiology 20, 537-543.

Le Marc, Y., Huchet, V., Bourgeois, C.M., Guyonnet, J.P., Mafart, P., Thuault, D., 2002. Modelling the growth kinetics of Listeria as a function of temperature, $\mathrm{pH}$ and organic acid concentration. International Journal of Food Microbiology 73, 219-237.

Maoz, A., Mayr, R., Sherer, S., 2003. Temporal stability and biodiversity of two complex antilisterial cheese-ripening microbial consortia. Applied and Environmental Microbiology 69, 4012-4018.

Margolles, A., Rodriguez, A., de los Reyes-Gavilán, C.G., 1997. Behavior of Listeria monocytogenes during the manufacture, ripening, and cold storage of Afuega'l Pitu cheese. Journal of Food Protection 60, 689-693.

Mayeux, J.V., Sandine, W.E., Elliker, P.R., 1962. A selective medium for detecting Leuconostoc organisms in mixed-strain starter culture. Journal of Dairy Science 45, 655-656.

Mayr, R., Fricker, M., Maoz, A., 2004. Anti-listerial activity and biodiversity of cheese surface cultures: influence of the ripening temperature regime. European Food Research Technology 218, 242-247.

Mellefont, L.A., McMeekin, T.A., Ross, T., 2008. Effect of relative inoculum concentration on Listeria monocytogenes growth in co-culture. International Journal of Food Microbiology 121, 157-168.

Millet, L., Saubusse, M., Didienne, R., Tessier, L., Montel, M.C., 2006. Control of Listeria monocytogenes in raw-milk cheeses. International Journal of Food Microbiology 108, 105-114.

Monnet, C. Correia, K, Sarthou, A.S, Irlinger, F, 2006. Quantitative detection of Corynebacterium casei in cheese by real-time PCR. Applied and Environmental Microbiology 72, 6972-6979.

Monnet, C., Bleicher, A., Neuhaus, K., Sarthou, A.S., Leclerq-Perlat, M.N., Irlinger, F. 2009. Assessment of the anti-listerial activity of microfloras from the surface of smearripened cheeses. Food Microbiology 1-9.

Mossel, D.A.A., Visser, M., Merrgerinsk, W.H.J., 1962. A comparison of media for the enumeration of moulds and yeasts in food and beverages. The Laboratory 11 109-112 Practical.

Motta, A.S., Brandelli, A., 2008. Properties and antimicrobial activity of the smear surface cheese coryneform bacterium Brevibacterium linens. European Food Research Technology 227, 1299-1306.

Nunez, M., Rodriguez, J.L., Garcia, E., Gaya, P., Medina, M., 1997. Inhibition of Listeria monocytogenes by enterocin 4 during the manufacture and ripening of Manchego cheese. Journal of Applied Microbiology 83, 671-677.

O'Sullivan, L., O'Connor, E.B., Ross, R.P., Hill, C., 2006. Evaluation of live-cultureproducing lacticin 3147 as a treatment for the control of Listeria monocytogenes on the surface of smear ripened cheese. Journal of Applied Microbiology 135-143.

Ong, L., Shah, N.P., 2009. Probiotic cheddar cheese: influence of ripening temperatures on proteolysis and sensory characteristics if cheddar cheeses. Journal of Food Science 74,5

Palles, T., Beresford, T., Condon, S., Cogan, T.M., 1998. Citrate metabolism in Lactobacillus casei and Lactobacillus plantarum. Journal of Applied Microbiology 85, 147-154.

Pearson, L.J., Marth, E.H., 1990. Listeria monocytogenes - threat to a safe food supply: a review. Journal of Dairy Science 73, 912-928.

Roth, E. Miesher Schwenninger, S., Hasler, M., Eugster-Meier, E, Lacroix, C, 2010 Population dynamics of two antilisterial cheese surface consortia revealed by temporal temperature gradient gel electrophoresis. BMC Microbiology 10, 74.

Saubusse, M., Millet, L., Delbes, C., Callon, C., Montel, M.C., 2007. Application of single strand conformation polymorphism - PCR method for distinguishing cheese 
bacterial communities that inhibit Listeria monocytogenes. International Journal of Food Microbiology 116, 126-135.

Skeie, S., Kieronczyk, A., Naess, R.M., Ostlie, H., 2008. Lactobacillus adjuncts in cheese: their influence on the degradation of citrate and serine during ripening of a washed curd cheese. International Dairy Journal 18, 158-168.

Slanetz, L.C.W., Bartley, C.H., 1957. Numbers of enterococci in water, sewage and feces determinated by the membrane filter technique with an improved medium. Journal of Bacteriology 74, 591-596.

Terzaghi, B.E., Sandine, W.E., 1975. Improved medium for lactic streptococci and their bacteriophages. Applied Microbiology 29, 807-813.
Wenzel, J.M., Marth, E.H., 1990. Changes in population of Listeria monocytogenes in a medium with internal $\mathrm{pH}$ control containing Streptococcus cremoris. International Journal of Dairy Science 73, 3357-3365.

Whitby, P.W., Carter, K.B., Burns, J.L., Royall, J.A., Lipuma, J.J., Stull, T.L., 2000. Identification and detection of Stenotrophomonas maltophilia by rRNA-directed PCR. Journal of Clinical Microbiology 38, 4305-4309.

Yadav, H., Jain, S., Sinha, P.R., 2007. Production of free fatty acids and conjugated linoleic acid in probiotic dahi containing Lactobacillus acidophilus and Lactobacillus casei during fermentation and storage. International Dairy Journal 16, 1006-1010. 